\title{
Effects of miglitol, an $\alpha$-glucosidase inhibitor, on glycaemic status and histopathological changes in islets in non-obese, non-insulin-dependent diabetic Goto-Kakizaki rats
}

\author{
Toshinao Goda $^{1 *}$, Kazuhito Suruga ${ }^{1}$, Akiko Komori ${ }^{1}$, Sachi Kuranuki ${ }^{1}$, Kazuki Mochizuki ${ }^{1}$, \\ Yumi Makita $^{2}$ and Toshihiko Kumazawa ${ }^{3}$ \\ ${ }^{1}$ Laboratory of Nutritional Physiology and COE Program in the 21st Century, University of Shizuoka School of Food \\ and Nutritional Sciences, 52-1 Yada, Shizuoka 422-8526, Japan \\ ${ }^{2}$ Mitsubishi Chemical Safety Institute Ltd., Ibaraki, Japan \\ ${ }^{3}$ Sanwa Kagaku Kenkyusho Co., Ltd., Nagoya, Japan \\ (Received 18 October 2006 - Revised 21 February 2007 - Accepted 9 March 2007)
}

Miglitol, a 1-deoxynojirimycin derivative, is an $\alpha$-glucosidase inhibitor. In the present study, the effects of acute (single-dose) and chronic (8-week) oral administration of miglitol in Goto-Kakizaki (GK) rats, an animal model of type 2 diabetes, were investigated. Dose-dependent decreases in incremental blood glucose concentrations integrated over a period of $2 \mathrm{~h}\left(\Delta \mathrm{AUC}_{0-2 \mathrm{~h}}\right)$ for values of blood glucose after sucrose-loading in miglitol-treated GK rats were observed following an acute oral administration of miglitol $(1,3 \mathrm{or} 10 \mathrm{mg} / \mathrm{kg} \mathrm{body} \mathrm{weight).} \mathrm{At} 10 \mathrm{mg} / \mathrm{kg}$, the $\triangle \mathrm{AUC}_{0-2 \mathrm{~h}}$ of blood glucose was decreased by $45 \%$ compared with the control group. Following the oral administration of miglitol in a dietary mixture $\left(10 \mathrm{mg}, 20 \mathrm{mg}\right.$ or $40 \mathrm{mg}$ miglitol $/ 100 \mathrm{~g}$ control diet) for 8 weeks, the ratio of $\mathrm{HbA}_{1 \mathrm{c}}$ at 8 weeks compared with 0 weeks in GK rats treated with $40 \mathrm{mg}$ miglitol $/ 100 \mathrm{~g}$ control diet miglitol was significantly decreased compared with control GK rats without changes in body weight. In oral glucose tolerance testing, miglitol caused a slight decrease in the $\Delta \mathrm{AUC}_{0-2 \mathrm{~h}}$ of plasma glucose concentration. In addition, miglitol treatment slightly inhibited the reduction in $\beta$-cell mass, and lessened the irregular contours and fibrosis of the islets in GK rats. These results indicate that miglitol ameliorates the hyperglycaemic state of GK rats and the impaired function of the pancreatic islets, as well as preventing the degeneration of islets in GK rats.

Miglitol: $\alpha$-Glucosidase inhibitor: $\beta$-Cell mass: GK rats

$\alpha$-Glucosidase inhibitors, which are oral antidiabetic agents, delay carbohydrate absorption from the small intestine by inhibiting intestinal $\alpha$-glucosidase activity. These drugs (e.g. acarbose, voglibose, miglitol) improve postprandial hyperglycaemia in diabetic patients ${ }^{1,2}$. Acarbose, a pseudotetrasaccharide, has been reported to be a competitive inhibitor of sucrase, glucoamylase and isomaltase ${ }^{3-6}$. Voglibose, an N-substituted valiolamine derivative, has been reported to have stronger $\alpha$-glucosidase inhibitory activity against maltase and sucrase ${ }^{7}$.

Miglitol, a 1-deoxynojirimycin derivative, is another drug selected for development as an antihyperglycaemic $\operatorname{drug}^{8}$. Miglitol is a strong inhibitor of glucoamylase, sucrase and isomaltase $^{9}$, and has been used clinically in Europe and the $\mathrm{USA}^{10,11}$. On the other hand, voglibose is not approved in Europe or the USA but has been widely used in the treatment of patients with diabetes in Asia. Miglitol causes less diarrhoea than acarbose and voglibose because it is almost completely absorbed in the upper region of the small intestine in rats, whereas acarbose and voglibose are not absorbed ${ }^{8,12}$.
Miglitol has recently been reported to reduce the plasma glucose concentration in a dose-dependent manner in normal rats $^{13}$ and in several animal models of diabetes ${ }^{14-16}$.

The question of whether or not a reduction in hyperglycaemia is achieved by acute or chronic oral administration of miglitol has not been investigated in Goto-Kakizaki (GK) rats, an animal model of non-obese, non-insulin-dependent diabetes characterised by low insulin secretion ${ }^{17,18}$. The effects of acarbose and voglibose have, however, already been investigated $^{19-23}$. It has been reported that $\beta$-cells in GK rats are defective in their glucose-stimulated insulin secretion, whereas insulin synthesis is not affected ${ }^{24-26}$. This animal model exhibits functional and structural features of diabetic complications and is therefore considered suitable for studying type 2 diabetes $^{27,28}$. It has also been reported that total $\beta$-cell mass was decreased in type 2 diabetic patients compared with control subjects $^{29}$ and that $\beta$-cell loss was enhanced by sucrose-feeding via an increase in the rate of apoptosis in GK rats ${ }^{30}$. Furthermore, a reduction in $\beta$-cell volume was found to be inhibited by a reduction of hyperglycaemia in GK rats treated with 
$\operatorname{voglibose}^{19}$. However, the effects of oral administration of miglitol for $\beta$-cell reduction as well as glycaemic control in GK rats are still unknown.

In the present study, we examined the acute effects of a single dose of miglitol on blood glucose concentrations and insulin secretion after sucrose-loading, as well as the chronic effects of long-term miglitol treatment in a dietary mixture on glycaemic control and $\beta$-cell reduction in GK rats.

\section{Materials and methods}

\section{Animals}

Diabetic GK male rats were obtained from CLEA Japan Inc., Japan. Non-diabetic Wistar male rats were purchased from Japan SLC (Hamamatsu, Japan). The rats had free access to standard laboratory chow (MF; Oriental Yeast, Tokyo, Japan) and water, and were housed in a room controlled for temperature $\left(22 \pm 3^{\circ} \mathrm{C}\right)$, humidity $(55 \pm 15 \%)$ and light (hours of time 07.00-19.00 hours).

\section{Effects of a single dose of miglitol in Goto-Kakizaki rats}

GK rats were randomly assigned to a group based on body weight and the results of oral glucose tolerance testing ( $2 \mathrm{~g} /$ $\mathrm{kg}$ body weight). Rats whose blood plasma glucose concentration was less than $300 \mathrm{mg} / \mathrm{dl}$ were excluded. Eight rats (10 weeks old) were used in each group and were fasted for $18-20 \mathrm{~h}$ before the experiments. The experimental procedures were approved by the Ethical Committee for Animal Research of Mitsubishi Chemical Safety Institute Ltd.

\section{Sucrose-loading test}

The rats were administered with a single oral dose of miglitol or voglibose (miglitol 1, 3, $10 \mathrm{mg} / \mathrm{kg}$ body weight; voglibose $0 \cdot 0125,0 \cdot 0375,0 \cdot 125 \mathrm{mg} / \mathrm{kg}$ body weight) dissolved in saline. Miglitol and voglibose provided by Bayer Yakuhin Ltd. (Osaka, Japan) were used in the present study. GK rats administered with only saline served as controls. The drug solutions were administered using a gastric tube in a volume of $5 \mathrm{ml} / \mathrm{kg}$ immediately before sucrose-loading ( $2 \mathrm{~g} / \mathrm{kg}$ body weight, $5 \mathrm{ml} /$ $\mathrm{kg}$ body weight).

Blood for glucose and insulin measurements was obtained from a subclavian vein at $0 \cdot 25,0 \cdot 5,1,2$ or $4 \mathrm{~h}$ after sucroseloading. Blood glucose was measured by the enzyme electrode method using a blood glucose meter (Horiba, Kyoto, Japan). Plasma insulin was estimated using an insulin ELISA kit (Morinaga Institute of Biological Science, Kanagawa, Japan). Glucose concentrations were calculated as the incremental blood glucose concentrations integrated over a period of $2 \mathrm{~h}\left(\Delta \mathrm{AUC}_{0-2 \mathrm{~h}}\right)$ after sucrose-loading.

\section{Effects of 8-week miglitol administration on Goto-Kakizaki rats}

All animals received the high-sucrose and high-fat control diet (Table 1) for 2 weeks before assignment to a study group.

Seven week-old male GK rats were assigned to one of six groups based on body weight and the results of the oral glucose tolerance test. Each group consisted of 5-7 animals.
Table 1. Composition of the high sucrose and high fat control diet

\begin{tabular}{|c|c|c|c|}
\hline & $\mathrm{g} / \mathrm{kg}$ & $\mathrm{kcal} / \mathrm{kg}$ & energy $\%$ \\
\hline Casein & $178 \cdot 7$ & $714 \cdot 8$ & $19 \cdot 9$ \\
\hline DL-Methionine & $2 \cdot 6$ & $10 \cdot 2$ & 0.3 \\
\hline$\alpha$-Cornstarch & $21 \cdot 3$ & $85 \cdot 2$ & $2 \cdot 4$ \\
\hline Sucrose & 425.5 & $1702 \cdot 0$ & 47.5 \\
\hline Corn oil & $66 \cdot 0$ & 594.0 & $16 \cdot 6$ \\
\hline Lard & 53.2 & 478.8 & $13 \cdot 4$ \\
\hline AIN $^{76}$ Mineral mix & 29.8 & - & \\
\hline AIN ${ }^{76}$ Vitamine mix & 8.5 & - & \\
\hline Choline bitartrate & 1.7 & - & \\
\hline $2 \%$ Agar & $212 \cdot 7$ & - & \\
\hline Total & 1000 & 3585 & 100 \\
\hline
\end{tabular}

Each experiment consisted of one control Wistar rat group and six GK rat groups as follows: (1) control Wistar rats fed the control diet; (2) control GK rats fed the control diet; (3) miglitol-treated GK rats fed a diet containing $10 \mathrm{mg}$ miglitol/100 g control diet; (4) miglitol-treated GK rats fed a diet containing $20 \mathrm{mg}$ miglitol $/ 100 \mathrm{~g}$ control diet; (5) miglitoltreated GK rats fed a diet containing $40 \mathrm{mg}$ miglitol $/ 100 \mathrm{~g}$ control diet; (6) voglibose-treated GK rats fed a diet containing $0.1 \mathrm{mg}$ voglibose $/ 100 \mathrm{~g}$ control diet; (7) voglibose-treated GK rats fed a diet containing $0.2 \mathrm{mg}$ voglibose $/ 100 \mathrm{~g}$ control diet. The rats were fed the control diet with either miglitol or voglibose ad libitum for 8 weeks. Feed mixtures containing miglitol or voglibose were prepared once a week.

The experimental procedures used in the present study conformed to the guidelines of the Animal Usage Committee of the University of Shizuoka.

\section{Parameters}

Blood glucose, body weight and food intake were measured after $0,2,4,6$ or 8 weeks of feeding. Physical signs were observed on an occasional basis.

$\mathrm{HbA}_{1 \mathrm{c}}$ was assayed by HPLC (Waters, Tokyo, Japan) using a TSKgel Boronate-5PW column system (Tosoh Corporation, Tokyo, Japan). Blood samples were collected for determination of plasma glucose after the rats were fasted overnight. Plasma glucose was measured by the glucose oxidase method using a commercial kit (Wako Pure Chemical Industries, Osaka, Japan).

After treatment for 8 weeks, all animals underwent an oral glucose tolerance test. The rats were orally administered a glucose solution $(2 \mathrm{~g} / \mathrm{kg}$ body weight, $10 \mathrm{ml} / \mathrm{kg}$ body weight) after an overnight fast, and their plasma glucose and plasma insulin concentrations were determined using blood samples from the tail vein $0,15,30,60$ and $120 \mathrm{~min}$ later. The data for GK rats given $0.2 \mathrm{mg}$ voglibose $/ 100 \mathrm{~g}$ control diet were excluded from the assessment because it appeared that energy restriction occurred as a result of diarrhoea in these rats.

After the oral glucose tolerance test, the animals were again given the control diet with miglitol or voglibose ad libitum by 23.00 hours. They were then fasted overnight and killed by decapitation. The whole pancreas was excised, weighed following the removal of connective tissue and extraneous fat, and then fixed in $3.7 \%(\mathrm{v} / \mathrm{v})$ formaldehyde and processed for paraffin embedding. 


\section{Islet pathology and morphometry of $\beta$-cells}

Serial $4 \mu \mathrm{m}$ thick paraffin sections were stained with haematoxylin \& eosin or azan for islet pathology and immunostained for morphometric analysis of islet $\beta$-cells. To identify the areas of $\beta$-cells in the islets, immunoperoxidase staining was performed using a Vectastain ABC kit (Vector Laboratories, Burlingame, CA, USA). Briefly, deparaffinised sections were first incubated with guinea-pig anti-insulin antibody (Dako, Carpinteria, CA, USA). The slides were then incubated with biotinylated anti-guinea-pig immunoglobulin antibody. The secondary reaction products were visualised with diamino-benzidine. Nuclei were lightly counterstained with haematoxylin.

Calculation of the volume density of $\beta$-cells was performed using an image processor for analytical pathology (IPAPWIN; Sumika Technoservice Corporation, Osaka, Japan). Areas of blood vessels, fat and connective tissue were excluded from the measurements. The identity of the sample was masked to the examiners during the process of morphometric analysis.

\section{Statistical analysis}

All experimental values are expressed as means with their standard errors for each group. Statistical analysis was
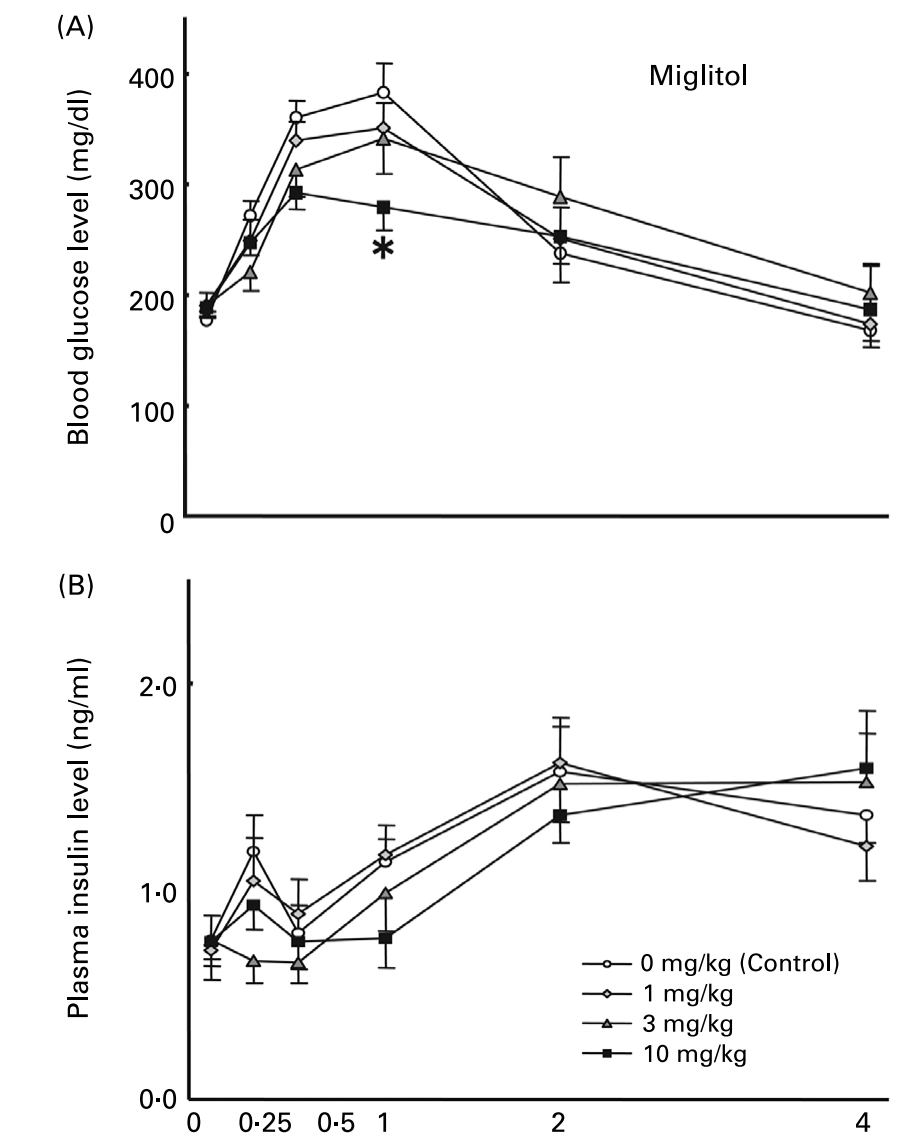

performed using Dunnett's test, analysis of linear regression and the Jonckheere-Terpstra test using SAS Proprietary Software (SAS Institute, Tokyo, Japan). The levels of body weight, food intake, blood glucose, plasma insulin and $\mathrm{HbA}_{1 \mathrm{c}}$ were compared between control GK rats and rats treated with several concentrations of miglitol or voglibose. The level of volume density of $\beta$-cells was compared between control Wister rats and GK rats with/without miglitol or voglibose treatment. A level of $P<0.05$ was considered to indicate statistical significance.

\section{Results}

Effects of a single dose of miglitol in Goto-Kakizaki rats

Blood glucose concentration. $\alpha$-Glucosidase inhibitors inhibit the digestion of sucrose in the lumen of the small intestine. To estimate the effect of miglitol on postprandial hyperglycaemia as a result of inhibiting sucrose digestion in the lumen, the blood glucose concentrations after sucrose loading were measured. Blood glucose reached the highest concentration $(382 \mathrm{mg} / \mathrm{dl}) 1 \mathrm{~h}$ after sucrose-loading in GK rats in the control group, following which values recovered to the pretreatment level at $4 \mathrm{~h}$ (Fig. 1(A)). Blood glucose concentrations were not significantly different between control GK rats and 1 or $3 \mathrm{mg} / \mathrm{kg}$ miglitol-treated GK rats. Blood

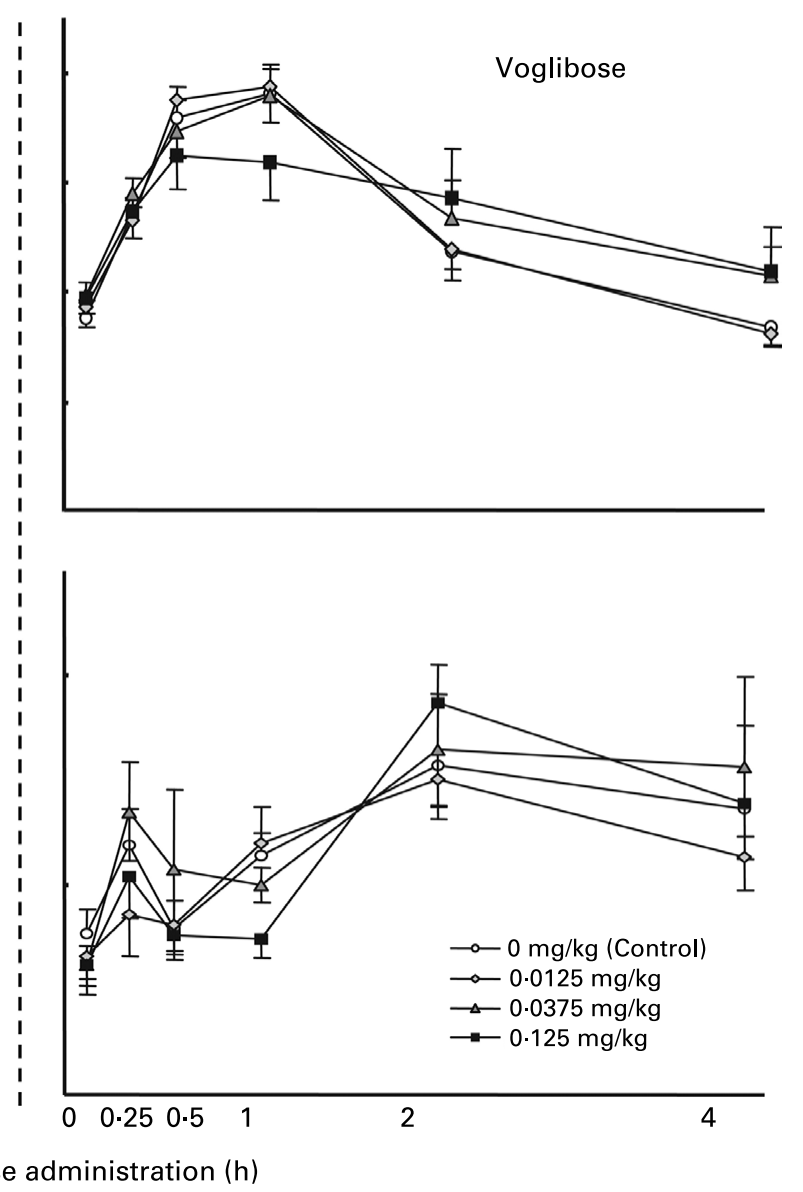

Fig. 1. Effects of miglitol (left panel) and voglibose (right panel) on concentrations of blood glucose (A) and plasma insulin (B) in sucrose-loaded Goto-Kakizaki rats. Mean values and their standard errors $(n 8)$. Mean values were significantly different from those of the control group (Dunnett's test): ${ }^{\star} P<0.05$. 
glucose concentrations in the $10 \mathrm{mg} / \mathrm{kg}$ miglitol-treated GK rats decreased significantly compared with the control group at $1 \mathrm{~h}$ after sucrose-loading $(P<0.05)$. In voglibose-treated GK rats, blood glucose concentrations were not significantly different from those of the control group at any dose.

The incremental blood glucose concentration integrated over a period of $2 \mathrm{~h}\left(\Delta \mathrm{AUC}_{0-2 \mathrm{~h}}\right.$ values $)$ after the administration of sucrose in the control group was $275 \mathrm{mg} / \mathrm{dl}$ per $\mathrm{h}$ (Table 2). At doses of 1 and $3 \mathrm{mg} / \mathrm{kg}$, miglitol did not affect the $\Delta \mathrm{AUC}_{0_{-2} \mathrm{~h}}$ of blood glucose. At $10 \mathrm{mg} / \mathrm{kg}$, the $\Delta \mathrm{AUC}_{0_{-}}$ $2 \mathrm{~h}$ of blood glucose fell by $45 \%$ compared with the control group $(P<0.05)$. None of the doses of voglibose affected the $\Delta \mathrm{AUC}_{0-2 \mathrm{~h}}$ of blood glucose.

Plasma insulin concentration. Plasma insulin concentrations were increased at $0.25 \mathrm{~h}$ after sucrose-loading in control GK rats and returned to pretreatment levels $0.5 \mathrm{~h}$ after sucroseloading (Fig. 1(B)). Thereafter, plasma insulin concentrations in control GK rats increased again $1 \mathrm{~h}$ after sucrose-loading and reached their highest values $(1.58 \mathrm{ng} / \mathrm{ml}) 2 \mathrm{~h}$ after sucroseloading.

In GK rats treated with $1 \mathrm{mg} / \mathrm{kg}$ miglitol, there was no effect on plasma insulin concentration compared with the control group. The plasma insulin concentration at $0 \cdot 25 \mathrm{~h}$ after sucrose-loading in the 3 and $10 \mathrm{mg} / \mathrm{kg}$ miglitol groups decreased by $44 \%$ and $22 \%$, respectively, compared with the control group, but the differences were not significant. Voglibose at doses of 0.0125 and $0.0375 \mathrm{mg} / \mathrm{kg}$ did not affect the plasma insulin concentration. Plasma insulin concentration $1 \mathrm{~h}$ after sucrose-loading in the $0.125 \mathrm{mg} / \mathrm{kg}$ voglibose-treated groups decreased by $35 \%$ compared with the control group, but was not significantly different from that of the control group.

\section{Effects of 8-week miglitol administration in Goto-Kakizaki rats}

Body weight and food intake. No differences in body weight were seen between the miglitol-treated and control GK rats (Table 3). Food intake in the miglitol-treated GK rats was decreased for 1 week after treatment but then returned to values similar to those of control Wistar and control GK

Table 2. Incremental blood glucose concentration in sucrose-loaded Goto-Kakizaki (GK) rats after a single dosage treatment with miglitol or voglibose

(Mean values with their standard errors)

\begin{tabular}{|c|c|c|c|c|}
\hline \multirow{2}{*}{$\begin{array}{l}\text { Test } \\
\text { substance }\end{array}$} & \multirow{2}{*}{$\begin{array}{c}\text { Dose } \\
(\mathrm{mg} / \mathrm{kg})\end{array}$} & \multirow{2}{*}{$\begin{array}{l}\text { Number of } \\
\text { animals }\end{array}$} & \multicolumn{2}{|c|}{$\begin{array}{l}\text { Glucose concen- } \\
\text { tration } \mathrm{AUC}_{0-2 \mathrm{~h}} \\
\quad(\mathrm{mg} / \mathrm{dl} \text { per } \mathrm{h})\end{array}$} \\
\hline & & & Mean & SE \\
\hline Control & - & 8 & 275 & 28 \\
\hline \multirow[t]{3}{*}{ Miglitol } & 1 & 8 & 220 & 29 \\
\hline & 3 & 8 & 215 & 34 \\
\hline & 10 & 8 & 151 & $37^{*}$ \\
\hline \multirow[t]{3}{*}{ Voglibose } & 0.0125 & 8 & 269 & 22 \\
\hline & 0.0375 & 8 & 250 & 43 \\
\hline & 0.125 & 8 & 205 & 59 \\
\hline
\end{tabular}

$\triangle \mathrm{AUC0}-2 \mathrm{~h}$, Incremental blood glucose concentration integrated over a period of $2 \mathrm{~h}$ in miglitol- or voglibose-treated GK rats.

Mean values were significantly different from those of the control group (Dunnett's test): ${ }^{*} P<0.05$. rats (Table 4). Physical signs in the miglitol-treated GK rats were normal throughout the treatment period.

In GK rats fed the diet containing $0.1 \mathrm{mg}$ voglibose $/ 100 \mathrm{~g}$ control diet, no difference in body weight was seen compared with control GK rats, even though food intake was decreased 1 week after the treatment before returning to values similar to those of control GK rats. On the other hand, diarrhoea was observed 1 day after treatment in GK rats administered the diet containing $0.2 \mathrm{mg}$ voglibose $/ 100 \mathrm{~g}$ control diet. The body weight of these latter rats was significantly decreased compared with control GK rats throughout the experimental period $(P<0.01, \quad P<0.001, \quad P<0.001$ and $P<0.001$ for weeks 2, 4, 6 and 8 respectively), whereas food intake was significantly reduced at each time point until 4 weeks $(P<0 \cdot 001$, $P<0.001$ and $P<0.001$, respectively).

$H b A_{1 c} . \mathrm{HbA}_{1 \mathrm{c}}$ concentrations were not significantly different between the control GK rats and the miglitol-treated GK rats (control, 6.90\% (SE 0.24); $10 \mathrm{mg}$ miglitol/100 g control diet, $6.49 \%$ (SE 0.11 ); $20 \mathrm{mg}$ miglitol $/ 100 \mathrm{~g}$ control diet, $6.30 \%$ (SE 0.18 ), $40 \mathrm{mg}$ miglitol $/ 100 \mathrm{~g}$ control diet, $6.45 \%$ (SE 0.19)). The $\mathrm{HbA}_{1 \mathrm{c}}$ ratio of 8 weeks to 0 week $\left(\Delta \mathrm{HbA}_{1 \mathrm{c}}\right.$ value) in miglitol-treated GK rats decreased in a dose-dependent manner (Fig. 2). In GK rats treated with $40 \mathrm{mg}$ miglitol/ $100 \mathrm{~g}$ control diet, $\Delta \mathrm{HbA}_{1 \mathrm{c}}$ was significantly decreased compared with control GK rats $(P<0 \cdot 01)$, although the value in GK rats fed the diet containing $0.1 \mathrm{mg}$ voglibose $/ 100 \mathrm{~g}$ control diet was similar to that in control $\mathrm{GK}$ rats $\left(\mathrm{HbA}_{1 \mathrm{c}}\right.$ value, $6.68 \%$ (SE 0.22); Fig. 2). In rats fed the diet containing $0.2 \mathrm{mg}$ voglibose $/ 100 \mathrm{~g}$ control diet, the $\mathrm{HbA}_{1 \mathrm{c}}$ value after 8 weeks of treatment $\left(\mathrm{HbA}_{1 \mathrm{c}}\right.$ value, $4.89 \%$ (SE 0.27)) decreased to a value similar to the level $\left(\mathrm{HbA}_{1 \mathrm{c}}\right.$ value, $5.07 \%$ (SE 0.12)).

An analysis of linear regression between the dosage of miglitol and the $\Delta \mathrm{HbA}_{1 \mathrm{c}}$ value showed clearly that treatment of the GK rats with miglitol reduced the $\Delta \mathrm{HbA}_{1 \mathrm{c}}$ value in a dose-dependent manner $\left(P=0.0007, R^{2}=0.386\right)$. Statistical treatment by Jonckheere-Terpstra analysis, which is well known for showing drug effects in a dose-dependent manner, indicated a significant tendency of $\mathrm{HbA}_{1 \mathrm{c}}$ to decrease with an increase in miglitol concentration $(P=0 \cdot 0007)$.

Oral glucose tolerance test. In the oral glucose tolerance test, blood glucose concentrations after glucose-loading were markedly elevated in GK rats, including control GK rats. In miglitol-treated GK rats, the reduction in the blood glucose concentration tended to occur earlier than that in control GK rats (Fig. 3(A)). The $\Delta \mathrm{AUC}_{0-2 \mathrm{~h}}$ of plasma glucose in miglitol-treated GK rats was not significantly different from that of control GK rats (Fig. 3(C)). In GK rats treated with $0.1 \mathrm{mg}$ voglibose $/ 100 \mathrm{~g}$ control diet, the plasma glucose concentration and $\Delta \mathrm{AUC}_{0-2 \mathrm{~h}}$ value of blood glucose were similar to those of control GK rats (Fig. 3(B), (C)).

Islet structure and morphometry. The weight of the pancreas in the control GK rats was greater than that of control Wistar rats by $42 \%$. With the exception of GK rats treated with $0.2 \mathrm{mg}$ voglibose $/ 100 \mathrm{~g}$ control diet, pancreas weight in GK rats treated with miglitol or voglibose was similar to that of control GK rats (Table 5).

Although the differences in $\beta$-cell volume density between control GK rats and miglitol-treated GK rats or voglibosetreated GK rats were not statistically significant, the reduction in $\beta$-cell volume density was slightly inhibited in GK rats treated with $40 \mathrm{mg}$ miglitol $/ 100 \mathrm{~g}$ control diet compared with 
Table 3. Body weight (g) of miglitol- and voglibose-treated Goto-Kakizaki (GK) rats (Means values with their standard errors)

\begin{tabular}{|c|c|c|c|c|c|c|c|c|c|c|c|c|c|}
\hline & \multirow{2}{*}{$\begin{array}{c}\text { Test } \\
\text { substance }\end{array}$} & \multirow{2}{*}{$\begin{array}{c}\text { Dose } \\
\text { (mg/100 g } \\
\text { control diet) }\end{array}$} & \multirow{2}{*}{$\begin{array}{l}\text { Number of } \\
\text { animals }\end{array}$} & \multicolumn{2}{|c|}{0 Weeks } & \multicolumn{2}{|c|}{2 Weeks } & \multicolumn{2}{|c|}{4 Weeks } & \multicolumn{2}{|c|}{6 Weeks } & \multicolumn{2}{|c|}{8 Weeks } \\
\hline & & & & Mean & SE & Mean & SE & Mean & SE & Mean & SE & Mean & $\mathrm{SE}$ \\
\hline Wistar & Control & - & 6 & 150 & 5 & 222 & 7 & 278 & 9 & 323 & 10 & 357 & 12 \\
\hline GK & Control & - & 6 & 144 & 4 & 222 & 4 & 280 & 5 & 322 & 7 & 358 & 9 \\
\hline \multirow[t]{3}{*}{ GK } & Miglitol & 10 & 7 & 145 & 5 & 219 & 6 & 274 & 7 & 312 & 8 & 347 & 8 \\
\hline & & 20 & 7 & 142 & 5 & 215 & 8 & 271 & 9 & 308 & 10 & 342 & 11 \\
\hline & & 40 & 6 & 140 & 5 & 214 & 6 & 267 & 6 & 303 & 6 & 335 & 6 \\
\hline \multirow[t]{2}{*}{ GK } & Voglibose & 0.1 & 7 & 141 & 6 & 213 & 4 & 269 & 5 & 305 & 6 & 332 & 7 \\
\hline & & 0.2 & 6 & 146 & 3 & 176 & $2^{\star \star}$ & 198 & $5^{\star \star \star}$ & 234 & $12^{\star \star *}$ & 259 & $15^{\star \star \star}$ \\
\hline
\end{tabular}

Mean values were significantly different from those of control GK rats (Dunnett's test): ${ }^{\star \star} P<0 \cdot 01,{ }^{\star \star \star} P<0 \cdot 001$.

control GK rats (Tabel 5). The volume density of $\beta$-cells in control GK rats tended to be reduced by $69 \%$ compared with that in control Wistar rats, but this was not significant $(P=0 \cdot 0556)$. On the other hand, the $\beta$-cell volume density of rats treated with $40 \mathrm{mg}$ miglitol $/ 100 \mathrm{~g}$ control diet was almost equal to that of control Wistar rats $(P=0.9949)$.

The islets of 15-week-old control GK rats showed irregular contours, fibrosis and loss of $\beta$-cells (Fig. 4), while those of age-matched control Wistar rats had a normal appearance. The islets of GK rats treated with the $40 \mathrm{mg}$ miglitol $/ 100 \mathrm{~g}$ control diet for 8 weeks showed good islet shape, and those of GK rats treated with $0 \cdot 1 \mathrm{mg}$ voglibose $/ 100 \mathrm{~g}$ control diet were similar to those of control GK rats.

\section{Discussion}

In the present study, we planed two separate experiments to explore the effects of acute and chronic oral administration of miglitol on GK rats, an animal model of non-obese, type 2 diabetes.

First, we examined the concentrations of blood glucose and plasma insulin after an oral administration of sucrose with or without miglitol in GK rats. At a dose of $10 \mathrm{mg}$ miglitol $/ \mathrm{kg}$ body weight, the $\Delta \mathrm{AUC}_{0-2 \mathrm{~h}}$ of blood glucose after sucroseloading decreased by $45 \%(P<0 \cdot 05$; see Table 2$)$. Our results clearly showed that blood glucose concentrations after sucrose-loading were decreased by a single dose of miglitol. For voglibose at a dose of $0.125 \mathrm{mg} / \mathrm{kg}$ body weight, the $\Delta \mathrm{AUC}_{0-2 \mathrm{~h}}$ of blood glucose after sucrose-loading decreased by $25 \%$ compared with control GK rats, but the difference was not significant. Odaka et al. reported that blood glucose concentrations in $0.1 \mathrm{mg} / \mathrm{kg}$ voglibose-treated $\mathrm{GK}$ rats decreased by more than $50 \%$ compared with control GK rats $^{31}$. Such discordant results may be attributable to differences between the colonies or ages of GK rats used for these studies because the glucose tolerances of the experimental animals, that is, fasting blood glucose or peak value of increasing blood glucose after sucrose-loading, were different between the present experiment and theirs. In GK rats, the reduction in $\beta$-cells becomes more pronounced and the frequency of diabetic syndrome, which is characterised by hyperglycaemia and impaired glucose tolerance, tends to rise with increasing age $\mathrm{e}^{30}$. Therefore, the age of the animals used in an experiment would appear to be very important.

Next, we investigated the effects on glycaemic status when GK rats were fed a diet containing miglitol for 8 weeks. During the 8-week experimental period, the $\Delta \mathrm{HbA}_{1 \mathrm{c}}$ in miglitol-treated GK rats decreased in a dose-dependent manner and was significantly decreased in rats treated with $40 \mathrm{mg}$ miglitol/ $100 \mathrm{~g}$ control diet compared with control GK rats, although $\Delta \mathrm{HbA}_{1 \mathrm{c}}$ in $\mathrm{GK}$ rats treated with $0.1 \mathrm{mg}$ voglibose $/ 100 \mathrm{~g}$ control diet was similar to that of control GK rats (see Fig. 2). This result indicates that chronic blood glucose concentrations in GK rats were controlled by miglitol.

It should be noted that $\Delta \mathrm{HbA}_{1 \mathrm{c}}$ was markedly reduced by treatment with the $0.2 \mathrm{mg}$ voglibose $/ 100 \mathrm{~g}$ control diet. Treatment with the latter diet induced diarrhoea and reduced food intake in GK rats (see Table 4). The high-sucrose and high-fat diet used in the present study may have accelerated the induction of gastrointestinal symptoms such as diarrhoea, which appeared only in rats treated with $0.2 \mathrm{mg}$ voglibose/ $100 \mathrm{~g}$ control diet. Thus, carbohydrate malabsorption

Table 4. Food intake (g) of miglitol- or voglibose-treated Goto-Kakizaki (GK) rats

(Mean values with their standard errors)

\begin{tabular}{|c|c|c|c|c|c|c|c|c|c|c|c|c|c|}
\hline & \multirow{2}{*}{$\begin{array}{c}\text { Test } \\
\text { substance }\end{array}$} & \multirow{2}{*}{$\begin{array}{c}\text { Dose }(\mathrm{mg} / 100 \mathrm{~g} \\
\text { control diet) }\end{array}$} & \multirow{2}{*}{$\begin{array}{l}\text { Number of } \\
\text { animals }\end{array}$} & \multicolumn{2}{|c|}{1 Week } & \multicolumn{2}{|c|}{2 Weeks } & \multicolumn{2}{|c|}{4 Weeks } & \multicolumn{2}{|c|}{6 Weeks } & \multicolumn{2}{|c|}{8 Weeks } \\
\hline & & & & Mean & SE & Mean & SE & Mean & SE & Mean & $\mathrm{SE}$ & Mean & $\mathrm{SE}$ \\
\hline Wistar & Control & - & 6 & $18 \cdot 2$ & 0.8 & $16 \cdot 7$ & 0.4 & $16 \cdot 0$ & 0.6 & $17 \cdot 5$ & $1 \cdot 2$ & $18 \cdot 4$ & $1 \cdot 1$ \\
\hline GK & Control & - & 6 & $16 \cdot 0$ & 0.1 & $16 \cdot 5$ & 0.2 & $16 \cdot 8$ & 0.5 & $17 \cdot 9$ & 0.4 & $17 \cdot 1$ & 0.2 \\
\hline \multirow[t]{3}{*}{ GK } & Miglitol & 10 & 7 & $14 \cdot 0$ & $0.5^{\star}$ & $17 \cdot 0$ & 0.7 & $17 \cdot 1$ & 0.8 & $18 \cdot 0$ & 0.9 & $17 \cdot 6$ & $1 \cdot 7$ \\
\hline & & 20 & 7 & $13 \cdot 2$ & $0.7^{\star \star}$ & $15 \cdot 9$ & 0.2 & $16 \cdot 4$ & 0.2 & $16 \cdot 7$ & 0.3 & $17 \cdot 2$ & 0.6 \\
\hline & & 40 & 6 & $13 \cdot 2$ & $0 \cdot 1^{\star *}$ & $16 \cdot 3$ & 0.2 & $16 \cdot 6$ & $1 \cdot 1$ & $16 \cdot 2$ & 0.5 & $16 \cdot 2$ & 0.4 \\
\hline \multirow[t]{2}{*}{ GK } & Voglibose & 0.1 & 7 & 11.9 & $0.4^{\star \star *}$ & $16 \cdot 0$ & 0.4 & $18 \cdot 0$ & 0.6 & $17 \cdot 0$ & 0.7 & $17 \cdot 2$ & 1.5 \\
\hline & & 0.2 & 6 & 7.8 & $0.3^{\star \star \star}$ & 11.6 & $0.5^{\star \star \star}$ & $10 \cdot 7$ & $1 \cdot 0^{\star \star \star \star}$ & 14.6 & 3.2 & $14 \cdot 3$ & 0.6 \\
\hline
\end{tabular}

Mean values were significantly different from those of control GK rats (Dunnett's test): ${ }^{\star} P<0.05,{ }^{\star \star} P<0.01,{ }^{* \star \star} P<0.001$. 


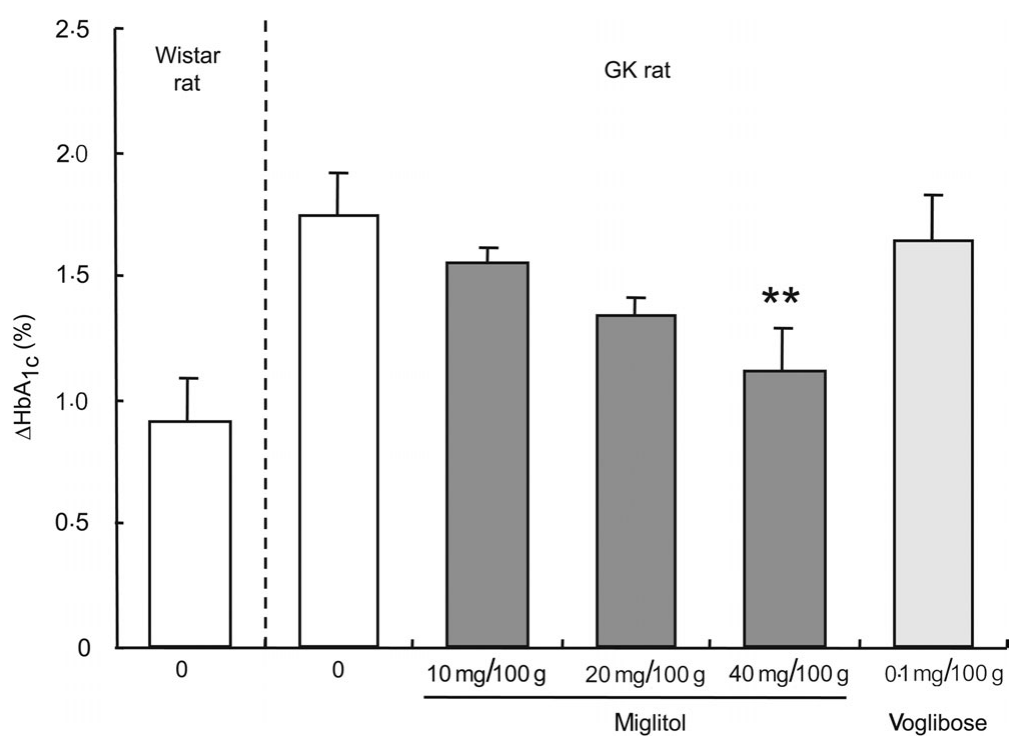

Fig. 2. $\Delta \mathrm{HbA}_{1 \mathrm{c}}$ concentrations for 8 weeks in miglitol- and voglibose-treated Goto-Kakizaki (GK) rats. Mean values and their standard errors ( $\left.n 5-7\right)$. Mean values were significantly different from those of control GK rats (Dunnett's test): ${ }^{\star \star} P<0.01$.
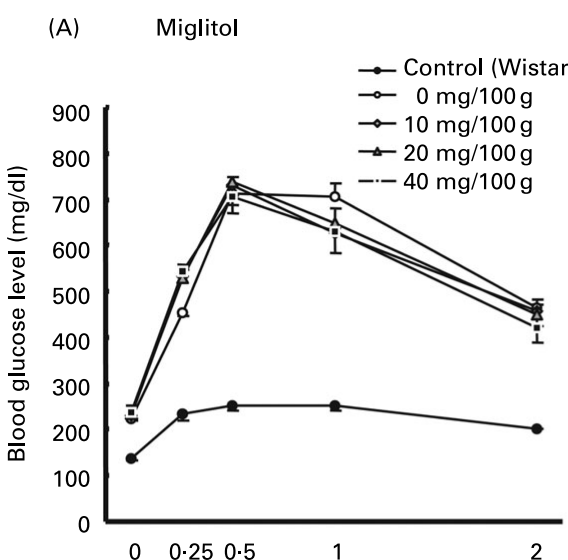

(B) voglibose

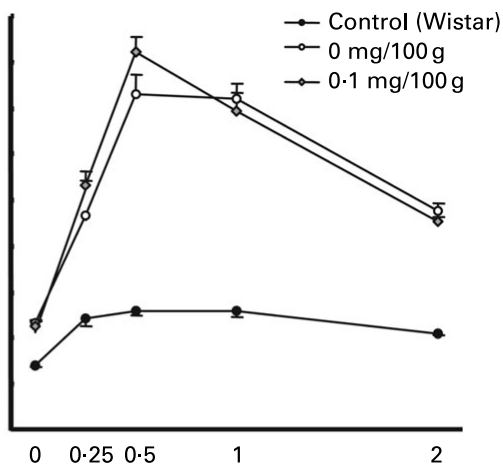

Time after sucrose administration (h)

(C)

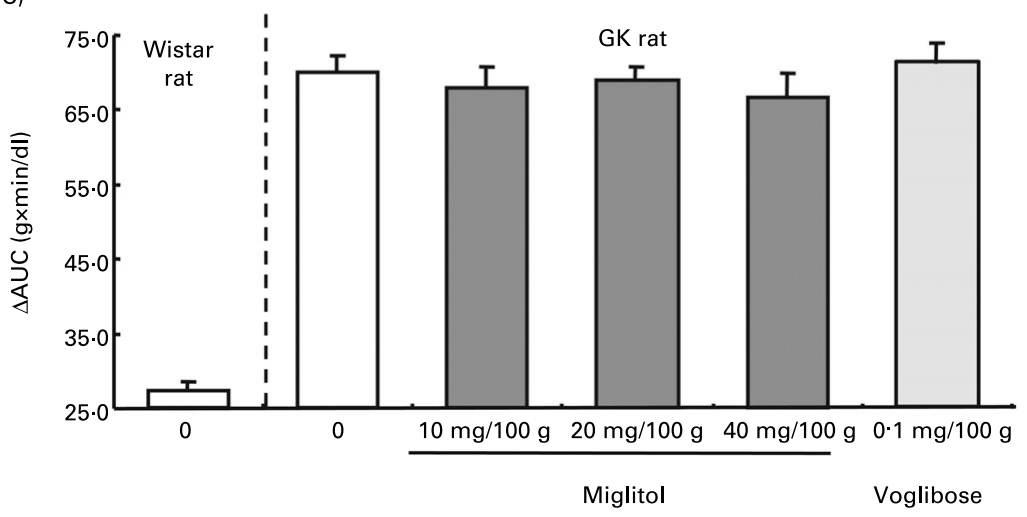

Fig. 3. Effects of miglitol (A) and voglibose (B) on plasma glucose concentration in glucose-loaded Goto-Kakizaki (GK) rats. Mean values and their standard errors ( $n$ 5-7). (C) Incremental blood glucose concentration integrated over a period of $2 \mathrm{~h}\left(\Delta \mathrm{AUC}_{0-2 \mathrm{~h}}\right)$ in glucose-loaded GK rats treated with miglitol or voglibose. Mean values and their standard errors $(n 5-7)$. 
Table 5. Pancreas weight and islet morphometry of miglitol- and voglibose-treated Goto-Kakizaki (GK) rats (Mean values with their standard errors)

\begin{tabular}{|c|c|c|c|c|c|c|c|c|c|}
\hline & \multirow[b]{2}{*}{ Test substance } & \multirow{2}{*}{$\begin{array}{l}\text { Dose (mg/100 g } \\
\text { control diet) }\end{array}$} & \multirow{2}{*}{$\begin{array}{l}\text { Number of } \\
\text { animals }\end{array}$} & \multicolumn{4}{|c|}{$\begin{array}{l}\text { Pancreas weight (mg) } \\
\text { (relative weight) }\end{array}$} & \multicolumn{2}{|c|}{$\begin{array}{c}\text { Volume density of } \\
\beta \text {-cells (\%) }\end{array}$} \\
\hline & & & & Mean & $\mathrm{SE}$ & Mean & SE & Mean & $\mathrm{SE}$ \\
\hline Wistar & Control & - & 6 & 758 & 37 & 226 & 16 & 1.02 & 0.06 \\
\hline GK & Control & - & 5 & 1078 & 23 & 310 & 11 & 0.70 & 0.03 \\
\hline \multirow[t]{3}{*}{ GK } & Miglitol & 10 & 7 & 1026 & 43 & 311 & 13 & 0.63 & 0.04 \\
\hline & & 20 & 6 & 1041 & 46 & 322 & 13 & 0.72 & 0.11 \\
\hline & & 40 & 6 & 1068 & 37 & 336 & 12 & 0.97 & 0.12 \\
\hline \multirow[t]{2}{*}{ GK } & Voglibose & 0.1 & 7 & 1080 & 31 & 341 & 15 & 0.82 & 0.05 \\
\hline & & 0.2 & 6 & 902 & $34^{\star \star}$ & 369 & $12^{*}$ & 0.72 & 0.11 \\
\hline
\end{tabular}

Mean values were significantly different from those of control GK rats (Dunnett's test): ${ }^{\star} P<0.05,{ }^{\star \star} P<0.01$.

occurs following a slight increase in the dose of a nonabsorbable $\alpha$-glucosidase inhibitor. Undigested carbohydrates enter the lower region of the small intestine, resulting in gastrointestinal disorders such as soft stools or diarrhoea. This suggests that the dosage range of voglibose for which gastrointestinal symptoms do not develop but for which the pharmacological action is seen is very narrow
(0.1-0.2 mg voglibose/100 g control diet). Miglitol did not produce diarrhoea even though it was administered at up to $100 \mathrm{mg} / 100 \mathrm{~g}$ diet in a toxicity study in normal Wistar rats for 12 months $^{32}$. Due to this attribute, miglitol exhibits a more potent inhibitory action on postprandial hyperglycaemia than other $\alpha$-glucosidase inhibitors, and without any adverse effects.
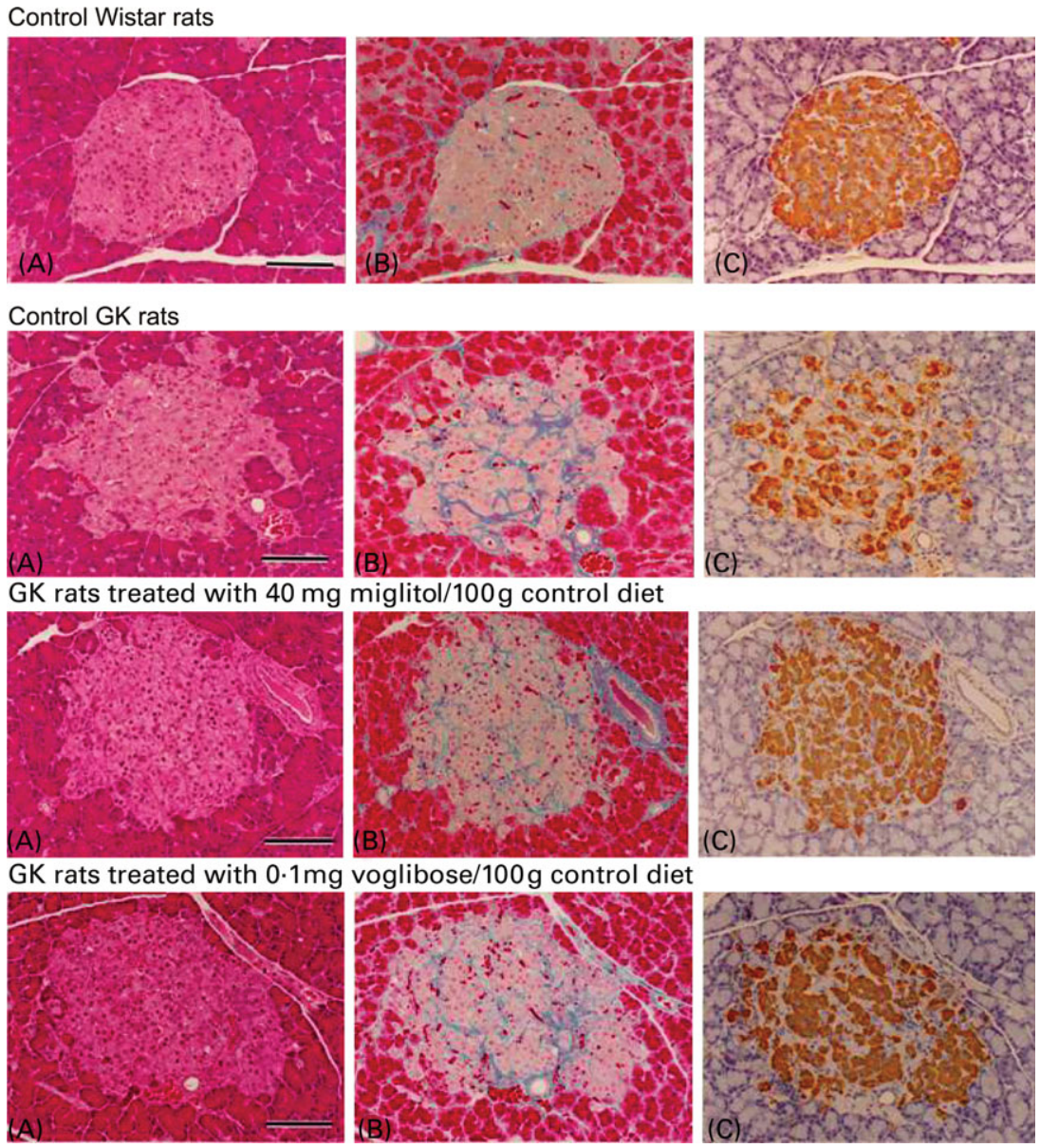

Fig. 4. Islet structures and distribution of immunoreactive insulin-positive cells ( $\beta$-cells) in miglitol- or voglibose-treated Goto-Kakizaki (GK) rats. Section from a control Wistar rat showing a normal structure: the islet is round in shape, with a clearly defined contour, and the $\beta$-cells (insulin-positive cells) are stained brown. Control GK rat and GK rat treated with $0.1 \mathrm{mg}$ voglibose $/ 100 \mathrm{~g}$ control diet, showing an irregular islet shape, a rough distribution of the $\beta$-cells and strands of fibrous tissue traversing the islet. GK rat treated with $40 \mathrm{mg}$ miglitol $/ 100 \mathrm{~g}$ control diet, showing good preservation of the islet. Scale bar $=100 \mu \mathrm{m}$. (A) Haematoxylin and eosin staining; (B) azan staining; (C) immunostaining for insulin. 
Finally, we examined the effects of miglitol on histological changes in the islets of GK rats. Histological changes in the islets of GK rats that have been reported include progressive fibrosis and the disappearance of $\beta$-cells with increasing age $^{27,33}$. The mechanism for the progressive loss of $\beta$-cells in GK rats is apoptotic cell death ${ }^{22,30,34}$. Furthermore, recent reports in which clinical information was better characterised have concluded that $\beta$-cell mass decreased in type 2 diabetes $^{29,34,35}$. In the present study, histological examination of the pancreas revealed that miglitol tended to inhibit the loss of $\beta$-cells as well as lessen irregular contouring and fibrosis of the islets in GK rats (see Fig. 4). Thus, the controlled blood glucose concentrations may be attributable to preservation of the islet $\beta$-cell mass.

The STOP-NIDDM trial has shown that decreasing postprandial blood glucose concentrations, as a consequence of acarbose treatment, could reduce the risk of diabetes in patients with impaired glucose tolerance ${ }^{36}$. A reduced demand for endogenous insulin by $\alpha$-glycosidase inhibitors, including miglitol, lessens the burden on a pancreas with decreased secretory capacity, which will potentially enable the preservation of pancreatic function over a long period in patients with type 2 diabetes.

In conclusion, miglitol ameliorates the hyperglycaemic state and impaired function of the pancreatic islets, and tends to inhibit the development of histological changes in the islets of GK rats.

\section{Acknowledgements}

This work was supported by COE Program in the 21st Century from the Ministry of Education, Science, Sports and Culture of Japan.

\section{References}

1. Inzucchi SE (2002) Oral antihyperglycemic therapy for type 2 diabetes: scientific review. JAMA 287, 360-372.

2. Scheen AJ (2003) Is there a role for alpha-glucosidase inhibitors in the prevention of type 2 diabetes mellitus? Drugs 63, 933-951.

3. Schmidt DD, Frommer W, Junge B, Muller L, Wingender W, Truscheit E \& Schafer D (1977) Alpha-glucosidase inhibitors. New complex oligosaccharides of microbial origin. Naturwissenschaften 64, 535-536.

4. Caspary WF \& Graf S (1979) Inhibition of human intestinal alpha-glucosidehydrolases by a new complex oligosaccharide. Res Exp Med (Berl) 175, 1-6.

5. Puls W, Keup U, Krause HP, Muller L \& Schmidt DD (1980) Pharmacology of a glucosidase inhibitor. Front Hormone Res 7, 235-247.

6. Goda T, Yamada K, Hosoya N \& Moriuchi S (1981) Effects of $\alpha$-glucosidase inhibitor BAY g 5421 on rat intestinal disaccharidases. J Jpn Soc Nutr Food Sci 34, 139-143.

7. Horii S (1993) Valiolamine and its N-substituted derivatives, alpha-D-glucosidase inhibitors: from validamycins to voglibose (AO-128), an antidiabetic agent. J Takeda Res Lab 52, 1-26.

8. Puls W, Krause HP, Muller L, Schutt H, Sitt R \& Thomas G (1984) Inhibitors of the rate of carbohydrate and lipid absorption by the intestine. Int J Obes 8, Suppl. 1, 181-190.

9. Samulitis BK, Goda T, Lee SM \& Koldovsky O (1987) Inhibitory mechanism of acarbose and 1-deoxynojirimycin derivatives on carbohydrases in rat small intestine. Drugs Exp Clin Res 13, 517-524.

10. Scott LJ \& Spencer CM (2000) Miglitol: a review of its therapeutic potential in type 2 diabetes mellitus. Drugs 59, 521-549.

11. Fehmann HC (2001) [The alpha-glucosidase inhibitor miglitol for the treatment of type 2 diabetes mellitus in the doctor's office]. Fortschr Med Orig 119, Suppl. 2, 55-61.

12. Ahr HJ, Boberg M, Brendel E, Krause HP \& Steinke W (1997) Pharmacokinetics of miglitol. Absorption, distribution, metabolism, and excretion following administration to rats, dogs, and man. Arzneimittelforschung 47, 734-745.

13. Tsukamoto K, Nakayama Y \& Mitsuzono T (2001) Pharmacological properties of miglitol, an alpha-glucosidase inhibitor, in rats. Jpn Pharmacol Ther 29, 623-633.

14. Madar Z (1989) The effect of acarbose and miglitol (BAY-M1099) on postprandial glucose levels following ingestion of various sources of starch by nondiabetic and streptozotocininduced diabetic rats. $J$ Nutr 119, 2023-2029.

15. Tormo MA, Ropero MF, Nieto M, Martinez IM \& Campillo JE (1998) Effect of miglitol administration to non-insulin-dependent diabetic rats. Gen Pharmacol 30, 125-129.

16. Russell JC, Graham SE \& Dolphin PJ (1999) Glucose tolerance and insulin resistance in the JCR:LA-corpulent rat: effect of miglitol (Bay m1099). Metabolism 48, 701-706.

17. Goto Y, Kakizaki M \& Masaki N (1975) Spontaneous diabetes produced by selective breeding of normal Wistar rats. Proc Jpn Acad 51, 80-85.

18. Goto Y \& Kakizaki M (1981) The spontaneous-diabetes rat: a model of noninsulin dependent diabetes mellitus. Proc Jpn Acad 57, 381-384.

19. Koyama M, Wada R, Mizukami H, Sakuraba H, Odaka H, Ikeda H \& Yagihashi S (2000) Inhibition of progressive reduction of islet beta-cell mass in spontaneously diabetic Goto-Kakizaki rats by alpha-glucosidase inhibitor. Metabolism 49, 347-352.

20. Yasuda K, Shimowada K, Uno M, et al. (2003) Long-term therapeutic effects of voglibose, a potent intestinal alpha-glucosidase inhibitor, in spontaneous diabetic GK rats. Diabetes Res Clin Pract 59, 113-122.

21. Wada R, Koyama M, Mizukami H, Odaka H, Ikeda H \& Yagihashi S (1999) Effects of long-term treatment with alphaglucosidase inhibitor on the peripheral nerve function and structure in Goto-Kakizaki rats: a genetic model for type 2 diabetes. Diabetes Metab Res Rev 15, 332-337.

22. Ihara $Y$, Toyokuni S, Uchida K, Odaka H, Tanaka T, Ikeda H, Hiai H, Seino Y \& Yamada Y (1999) Hyperglycemia causes oxidative stress in pancreatic beta-cells of GK rats, a model of type 2 diabetes. Diabetes 48, 927-932.

23. Azuma K, Toyofuku Y, Iesaki T, et al. (2006) Acarbose, an alpha-glucosidase inhibitor, improves endothelial dysfunction in Goto-Kakizaki rats exhibiting repetitive blood glucose fluctuation. Biochem Biophys Res Commun 345, 688-693.

24. Portha B, Serradas P, Bailbe D, Suzuki K, Goto Y \& Giroix MH (1991) Beta-cell insensitivity to glucose in the GK rat, a spontaneous nonobese model for type II diabetes. Diabetes $\mathbf{4 0}$, 486-491.

25. Ostenson CG, Khan A, Abdel-Halim SM, Guenifi A, Suzuki K, Goto Y \& Efendic S (1993) Abnormal insulin secretion and glucose metabolism in pancreatic islets from the spontaneously diabetic GK rat. Diabetologia 36, 3-8.

26. Giroix MH, Vesco L \& Portha B (1993) Functional and metabolic perturbations in isolated pancreatic islets from the GK rat, a genetic model of noninsulin-dependent diabetes. Endocrinology 132, 815-822.

27. Goto Y, Suzuki K, Ono T, Sasaki M \& Toyota T (1988) Development of diabetes in the non-obese NIDDM rat (GK rat). Adv Exp Med Biol 246, 29-31. 
28. Suzuki K-I, Goto Y \& Toyota T (1990) Spontaneously diabetic GK (Goto-Kakizaki) rats. In Lessons from Animal Diabetes, vol. IV, pp. 116-107 [E Shafrir, editor]. Boston: Birkhauser.

29. Clark A, Wells CA, Buley ID, Cruickshank JK, Vanhegan RI, Matthews DR, Cooper GJ, Holman RR \& Turner RC (1988) Islet amyloid, increased A-cells, reduced B-cells and exocrine fibrosis: quantitative changes in the pancreas in type 2 diabetes. Diabetes Res 9, 151-159.

30. Koyama M, Wada R, Sakuraba H, Mizukami H \& Yagihashi S (1998) Accelerated loss of islet beta cells in sucrose-fed GotoKakizaki rats, a genetic model of non-insulin-dependent diabetes mellitus. Am J Pathol 153, 537-545.

31. Odaka H, Sano Y, Amano N \& Ikeda H (1994) Effect of AO-128 alone or in combination with sulfonylurea on fasting blood glucose and postprandial hyperglycemia in normal and diabetic rats. Jpn Pharmacol Ther 22, 2665-2674.

32. Bomhard E (1996) Toxicology of glucosidase inhibitors. In Handbook of Experimental Pharmacology: Oral Antidiabetics, pp. 557-610 [J Kuhlmann and W Puls, editors]. Berlin: Springer Verlag.

33. Guenifi A, Abdel-Halim SM, Hoog A, Falkmer S \& Ostenson CG (1995) Preserved beta-cell density in the endocrine pancreas of young, spontaneously diabetic Goto-Kakizaki (GK) rats. Pancreas 10, 148-153.

34. Miralles F \& Portha B (2001) Early development of beta-cells is impaired in the GK rat model of type 2 diabetes. Diabetes 50, Suppl. 1, S84-S88.

35. Butler AE, Janson J, Soeller WC \& Butler PC (2003) Increased beta-cell apoptosis prevents adaptive increase in beta-cell mass in mouse model of type 2 diabetes: evidence for role of islet amyloid formation rather than direct action of amyloid. Diabetes 52, 2304-2314.

36. Chiasson JL, Josse RG, Gomis R, Hanefeld M, Karasik A \& Laakso M (2002) Acarbose for prevention of type 2 diabetes mellitus: the STOP-NIDDM randomised trial. Lancet 359, 2072-2077. 